\title{
Changes in bacterioplankton density and viability in the Tordera river due to the input of effluents from waste water treatment plants
}

\author{
Zoraida Vivas*, Núria Perujo, Anna Freixa and Anna M. Romaní \\ Institute of Aquatic Ecology, University of Girona, E-17071 Girona, Spain. \\ * Corresponding author: zoraidavg@gmail.com
}

Received: 06/11/16

Accepted: 27/02/17

\begin{abstract}
Changes in bacterioplankton density and viability in the Tordera river due to the input of effluents from waste water treatment plants

In middle and lower river basin reaches, bacterioplankton communities are usually found and their development and dynamics depend on the physico-chemical characteristics of the water, the inputs from tributaries, as well as the interactions these communities establish with the riverbed. The aim of this study was to assess whether direct inputs of effluents from wastewater treatment plants (WWTP) to the river generated significant changes in the density and viability of bacterioplankton communities. To achieve this objective, prokaryote density and physico-chemical characteristics in river water were analysed just before and after two WWTP located in the middle and lower parts of the Tordera river basin, as well as in each WWTP effluent. Five samplings were carried out during a base flow period. Moreover, in two occasions, prokaryote density at the riverbed sediment was also measured in order to assess the possible link between benthic and planktonic compartments. Results showed that WWTP effluents carried more prokaryotes and nutrients and had higher temperature than the river reaches receiving such effluents, being their impact more significant in the mid-river than in the low-river reach. In the mid-river reach, WWTP effluent input increased prokaryotic density which may be determined by the higher availability of phosphate and dissolved organic matter which might favour its development, as it is also suggested by the observed increase of prokaryote viability together with a prokaryote cell density which was larger than that predicted from the river and the WWTP effluent prokaryote loads. In contrast, at the down-river reach, prokaryote density was almost not affected by the WWTP effluent input. In this reach, prokaryote viability decreased at the river waters downstream the WWTP. It is suggested that the low oxygen concentration in the WWTP effluent was not favouring bacterioplankton growth, while the lower flow velocity may have favoured the settlement of prokaryote cells at the riverbed, as suggested by the increase in cell density in river sediments. Results showed that river bacteriplankton state is highly dynamic and responsive (viability ranged from 13 to 57\%) when receiving effluents with distinct characteristics. Our results suggest that the expected response of increasing river bacterioplankton density and viability when receiving effluents with high loads of nutrients and organic matter will be alleviated by specific physical and chemical characteristics of the main effluent which may inhibit prokaryote growth and/or by specific riverbed characteristics which hold the development of an active benthic microbial community.
\end{abstract}

Key words: Bacterioplankton, WWTP, Tordera river, prokaryote viability, sediment, nutrients, flow cytometry.

\section{RESUMEN}

Cambios en la densidad y viabilidad del bacterioplancton en el río Tordera debido a las entradas de efluentes de estaciones depuradoras de aguas residuales

En los tramos medios y bajos de cuenca se suelen encontrar comunidades bacterioplanctónicas, cuyo desarrollo y dinámica depende de las características físico-químicas del agua, de la entrada de cursos tributarios, así como de las interacciones que estas comunidades establecen con el lecho fluvial. El objetivo del presente estudio fue evaluar si la entrada directa de vertidos procedentes de estaciones depuradoras de aguas residuales (EDAR) al río generaba cambios significativos en la densidad y viabilidad de las comunidades bacterioplanctónicas. Para alcanzar este objetivo se analizó la densidad de procariotas y las características físico-químicas del agua en los puntos del río Tordera situados justo antes y después de dos EDAR ubicadas en los tramos medio y bajo de cuenca, así como en el efluente de salida de cada EDAR. Para ello se realizaron cinco muestreos durante un período de caudal basal. También, en dos ocasiones, se midió la densidad de procariotas en el sedimento del río, con la finalidad de valorar la posible relación entre los compartimentos bentónicos y planctónicos. Se observa que el efluente de salida de las EDAR contuvo más procariotas, más nutrientes y una temperatura más elevada que los tramos 
receptores de dichos vertidos, siendo su impacto más significativo en el tramo medio que en el tramo bajo de cuenca. En el tramo medio, la entrada del vertido de la EDAR aumentó la densidad de procariotas, lo que pudo venir determinado por la mayor disponibilidad de fosfatos y materia orgánica disuelta, pudiendo favorecer su desarrollo, como también sugiere el aumento de la viabilidad de procariotas observada en el agua del río, conjuntamente con una densidad de procariotas más elevada que la predicha a partir de la carga de procariotas del río y del efluente de la EDAR. Al contrario, en el tramo bajo de cuenca, la densidad de procariotas no se vio casi afectada por la entrada del vertido de la EDAR. En este tramo la viabilidad de procariotas disminuyó aguas abajo de la EDAR. La baja concentración de oxígeno disuelto en el vertido de la EDAR probablemente no favoreció el crecimiento del bacterioplancton, mientras que la baja velocidad del agua podría haber favorecido el asentamiento de células procariotas en el lecho del río, tal y como sugiere el aumento de su densidad en el sedimento. Los resultados indican que el estado del bacterioplancton del río es altamente dinámico y sensible (el rango de viabilidad fluctuó del 13 al 57\%) cuando recibe efluentes con características distintas. Los resultados obtenidos sugieren que la respuesta esperada de un aumento de la densidad y viabilidad del bacterioplancton al recibir efluentes con elevada carga de nutrientes y materia orgánica se verá aliviado por características físicas y químicas del propio efluente que puedan inhibir el crecimiento de procariotas y/o por características específicas del lecho fluvial que acojan el desarrollo de una comunidad microbiana bentónica activa

Palabras clave: Bacterioplancton, EDAR, río Tordera, viabilidad de procariotas, sedimento, nutrientes, citometría de flujo.

\section{INTRODUCTION}

Bacteria are the most abundant organisms on Earth. They are responsible for key environmental processes such as nutrient cycling and organic matter decomposition (Cotner \& Biddanda, 2002). In aquatic ecosystems, bacterioplankton plays a key role in the microbial loop by incorporating organic matter and nutrients to its biomass and transferring it to higher trophic levels or either fluxing carbon to the atmosphere (Azam et al., 1983). In rivers, bacterioplankton includes a wide range of autotrophic and heterotrophic organisms which show spatial and temporal dynamics highly affected by discharge and water flow velocities (Margalef, 1983; Reynolds, 2000; Chiaramonte et al., 2013). River bacterioplankton typically develops in mid to lower reaches where lower current velocities and availability of nutrients and dissolved organic matter favour the development of these microbial communities (Reynolds, 2000). For instance, the abundance of bacterioplankton in a lowland river was highly determined by carbon, temperature, chlorophyll and nutrient availability (Szelag-Wasielewska et al. (2009). Thus, density of bacteria in rivers may fluctuate along the watershed. Bacterial gaining and loosing processes may occur due to direct contact with the benthic community which may act both as a sink (settlement and/or attach- ment of cells to the benthic compartment) or a source (by detachment of bacteria to the water column) mainly depending on the flow and the physico-chemical conditions (Rehmann \& Soupir, 2009). Specifically, it has been suggested that bacteria from benthic sediments and biofilms may feed the bacterioplankton river community (Portillo et al., 2012). Tributaries can also act as significant input of bacterial cells to the main stem. Bacterioplankton abundance is also dependent on human development. For instance, the effluents from waste water treatment plants (WWTP) can introduce important inputs of bacteria. Moreover, WWTP often discharge their effluents directly into lotic ecosystems, increasing river flow (Brooks et al., 2006). At the same time, WWTP effluents may significantly alter the physico-chemical conditions of the receiver river reach by increasing the nutrient load and the dissolved organic carbon content, favouring eutrophication processes and bacterial growth (Waiser et al., 2001; Gücker et al., 2006). On the contrary, WWTP effluents may also eject a toxic effect on bacteria due to the strong change in water conductivity and/or the increase of toxic compounds (Echarri, 2007). Also, as reported by Odum et al. (1979), bacteria can respond to nutrient and organic matter inputs by a subsidy effect or a stress effect, depending on their concentrations. 
River bacterioplankton is composed by cells that grow and develop in a planktonic form, and by cells that are merely transported downstream being drifted from the sediment and that are mainly dead or inactive. Actually, a large fraction of the bacterial planktonic community is inactive and do not play a direct biogeochemical role for the ecosystem. It is then relevant in these systems to discriminate active from non-active cells. For instance, bacterial viability in freshwater ecosystems showed values from $7 \%$ in oligotrophic lakes, to $75 \%$ in polluted rivers (Porter et al., 1995). Grégory et al. (2001) reported that the effluent from a WWTP reduced the viability of cells from $61 \%$ (upstream) to $40 \%$, increasing until $65 \%$ six kilometres downstream.

The aim of this study was to determine the effects of WWTP effluents on the density and viability of prokaryotic cells in rivers. Specifically, we investigated the changes in bacterioplankton density and viability before and after the input of two WWTP in a Mediterranean river system for five consecutive sampling campaigns during a base flow period. Complementary to the bacterioplankton measurements, bacterial density at the benthic sediment was also measured in two sampling campaigns in order to assess the possible link between the benthic and the planktonic compartments. We expect that river water bacterioplankton density and viability will be modified after the input of WWTP, affected by the bacterial load and viability of the WWTP effluent, and also by the physico-chemical conditions of the own WWTP effluent. Specially, we expect that bacterial viability would be favoured by availability of nutrients from the WWTP effluent but this could depend on the concentration of these nutrients in the effluents.

\section{METHODS}

\section{Study Area}

The Tordera river $\left(877 \mathrm{~km}^{2}\right.$ watershed area) is a Mediterranean river located about $60 \mathrm{~km}$ northeast of Barcelona city (Fig. 1). The Tordera river is $60 \mathrm{~km}$ long, draining the Montseny mountains (maximum height 1700 m.a.s.1.) to the Mediterranean Sea. The climate is Mediterranean subhumid with severe droughts in summer. Mean temperature ranges between 5 and $10{ }^{\circ} \mathrm{C}$ in winter (November-March) and 20 to $25^{\circ} \mathrm{C}$ in summer (July to September; AEMET, 2010). The hydrological regime mainly follows the rainy pattern, with low or intermittent flow during summer and high and permanent flow at the end of autumn and early spring. The river flow is very variable both seasonally and inter-annually. Mean annual precipitation is $792 \mathrm{~mm}$ and mean annual discharge is $4 \mathrm{~m}^{3} / \mathrm{s}$ (measured at $7.5 \mathrm{~km}$ upstream from the low-river reach study site, Fig. 1) (ACA, 2002; Rovira \& Batalla, 2006).

With the exception of a small dam in the headwaters, there are no other reservoirs along this river. The $77 \%$ of the catchment is forested (mainly composed of evergreen oak forest and some plantations of black poplar and plane tree at the floodplain) and the remaining $16 \%$ and $7 \%$ are crops (in the alluvial deposits) and urbanindustrial areas, respectively (Rovira \& Batalla, 2006; Caille et al., 2007). Population density ranged from less that 100 (headwaters) to 20 000 inhab. $/ \mathrm{km}^{2}$ (urban zones). The river network receives the effluents from 13 waste water treatment plants and 10-15 industries (Catalan Water Authorities, ACA, acamap.gencat.cat).

In this study we focused on two river reaches of the Tordera river affected by WWTP inputs: the Palautordera reach (mid-river reach) which receives the inputs from the WWTP of Santa Maria de Palautordera village (treating 11663 inhabitants equivalents), and the Tordera reach (low-river reach) which receives the inputs from the WWTP of Tordera village (treating 21667 inhabitants equivalents) (Fig. 1). Both WWTP pour their effluents directly to the Tordera river. The two WWTP are, from the source to the mouth, the first and the last punctual effluents in the Tordera river, respectively.

\section{Sampling design}

In order to study the changes in the bacterioplankton as a consequence of WWTP inputs, we defined three sampling sites at each of the two 
selected river reaches: a site located $50 \mathrm{~m}$ upstream from the WWTP (named BEFORE), a site located at the outflow from the WWTP, just before entering the river (named WWTP), and a site located $50 \mathrm{~m}$ downstream to the WWTP (named AFTER, Fig. 1). Altogether we performed 5 sampling campaigns during a base flow period (from September to December 2013). On each sampling day we collected water samples from the six sites. Three replicates were collected at each site $(10 \mathrm{~cm}$ water depth) by following a cross-sectional transects perpendicular to the river channel. Samples for prokaryote density and viability were collected in sterilized $20 \mathrm{~mL}$ glass vials which were stored at $4{ }^{\circ} \mathrm{C}$ until analysis. Samples for prokaryote density were fixed with formaldehyde solution (final concentration $2 \%$ ), whereas samples for viability were transported in fresh and stained in the laboratory on the same sampling day as described below.
Furthermore, on the last two sampling campaigns we collected sediment samples from BEFORE and AFTER sites at each river reach to determine prokaryote density. Surface sediment (up to $2 \mathrm{~cm}$ depth) was collected by a $4.5 \mathrm{~cm}$ diameter methacrylate corer sampler. From this core, a subsample of about $1 \mathrm{~cm}^{3}$ volume (aprox. $1 \mathrm{~g}$ sediment) was collected with an uncapped syringe and placed in a $20 \mathrm{~mL}$ sterilized glass vial. At each site, sediment samples were collected in triplicate following the same longitudinal transect as that defined for the water samples. Sediment samples were fixed in formaldehyde solution (final concentration 2\%) and maintained at $4{ }^{\circ} \mathrm{C}$ until being processed.

\section{River physico-chemical conditions}

On each sampling campaign and site, several physico-chemical parameters were measured, by

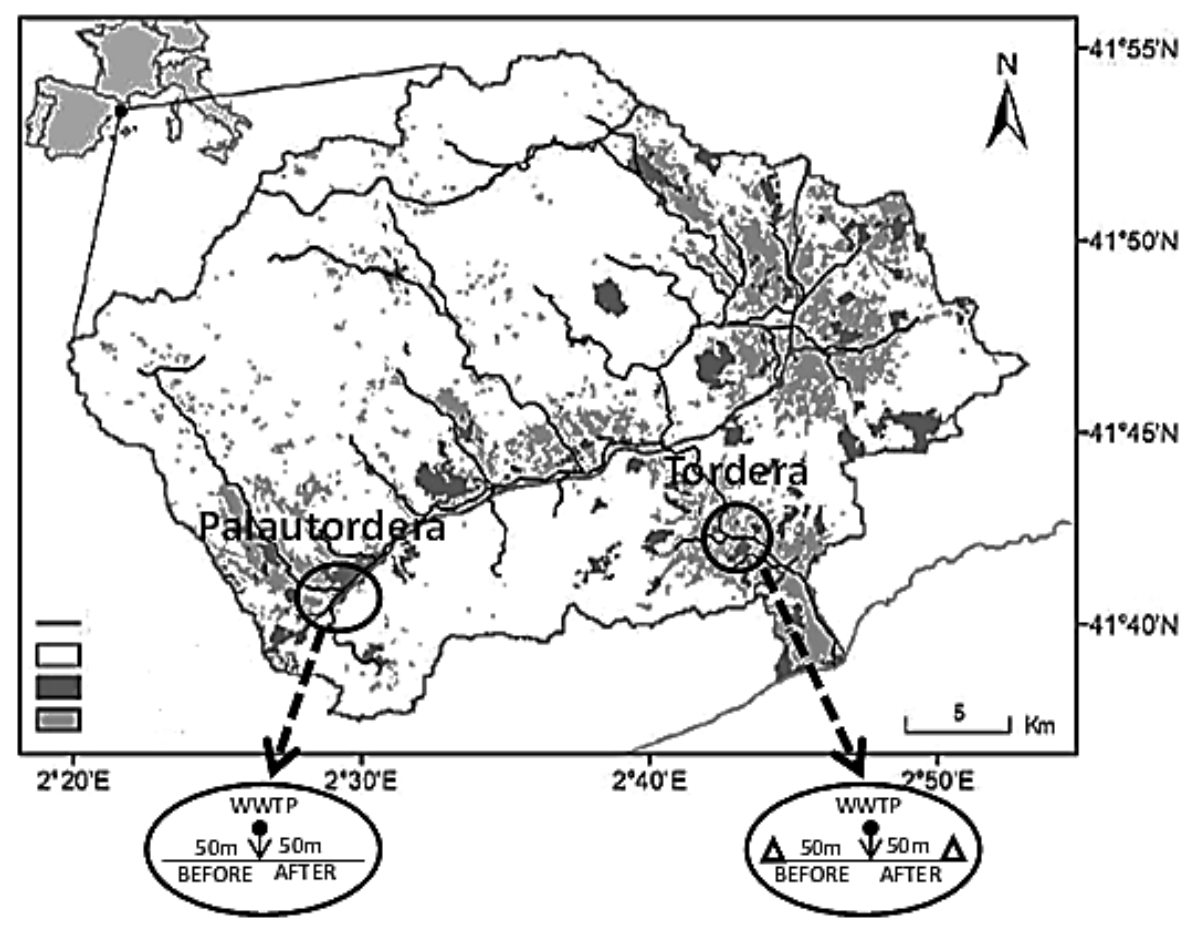

Figure 1. Location of the Tordera river in the Iberian Peninsula with further information from the main soil use in the fluvial network (from ICC, "Institut Cartogràfic de Catalunya"). The two study reaches in Palautordera (mid-river reach) and Tordera (lowriver reach) are indicated as well as the three sampling sites (Before, WWTP, After) for each reach. Localización del río Tordera e información de los usos del suelo más relevantes en la cuenca de estudio (ICC, "Institut Cartogràfic de Catalunya"). Se indican los dos tramos de estudio en Palautordera y Tordera y los tres puntos de muestreo (Before, WWTP, After) en cada tramo. 
triplicate, in the river water (following the same cross-sectional transect as that defined for water samples). Temperature, dissolved oxygen, conductivity and $\mathrm{pH}$ were measured with a multiparameter probe HQ30d Flexi. Samples for chemical analysis were collected and filtered in the field as follows. Samples for nutrients (15 ml) and Dissolved Organic Carbon (DOC, $20 \mathrm{~mL}$ ) were filtered by glass microfiber filters $(0.7 \mu \mathrm{m}$ pore size, Whatman $\mathrm{GF} / \mathrm{F})$. Glass vials and fiber filters for DOC had been previously burned ( 4 hours at $450{ }^{\circ} \mathrm{C}$ ). Once in the laboratory, samples for DOC were acidified by adding $100 \mu \mathrm{L}$ of $\mathrm{HCl}$. Samples for inorganic nutrients were stored frozen until analysis. Nitrate was analysed by ion chromatography with 761 Compact IC 1.1 (Metrohm), phosphate was analysed colorimetrically following the Murphy and Riley (1962) protocol, and ammonium was analysed by the salicylate method (Reardon et al,. 1966). Results for inorganic nutrients are given in $\mathrm{mg} / \mathrm{L}$ of $\mathrm{N}$ and $\mathrm{P}\left(\mathrm{N}-\mathrm{NO}_{3}, \mathrm{~N}-\mathrm{NH}_{4}\right.$, and $\left.\mathrm{P}-\mathrm{PO}_{4}\right)$. DOC concentration was determined using a Shimadzu TOC Analyser (TOC-VCSH). Discharge and level data for the two studied river reaches during the study period, and theoretical discharge from the two WWTP were obtained from the ACA.

\section{Prokaryote density}

Prokaryote density in water and sediment samples was measured by flow cytometry. Water samples were first diluted (1/10) with a detaching solution. Detaching solution consists of $\mathrm{NaCl}(130 \mathrm{mM}), \mathrm{Na}_{2} \mathrm{HPO}_{4}(7 \mathrm{mM}), \mathrm{NaH}_{2} \mathrm{PO}_{4}$ (3 $\mathrm{mM})$, formaldehyde (37\%), sodium pyrophosphate decahydrate $99 \%$ (0.1\% final concentration), and tween 20 (0.5\% final concentration), and it helps to separate cells and avoid aggregation (Amalfitano et al., 2009). Samples were mixed with vortex in order to obtain a homogenous sample. A subsample $(400 \mu \mathrm{L})$ of each diluted sample was placed into polypropylene tubes suitable for cytometer and $4 \mu \mathrm{L}$ of SYTO13 (Fisher, $5 \mathrm{mM}$ solution) were added. Samples were incubated for 15 minutes for the staining of the cells. SYTO13 specifically stains DNA and allows us to count prokaryotes. Then,
$10 \mu \mathrm{L}$ of beads solution (Polysciences latex balls $10^{6} \mathrm{~mL}^{-1}$ solution, FISHER $1.0 \mu \mathrm{m}$ ) were added to each tube as internal reference and proceeded to read counts by the flow cytometer.

Sediment samples were also diluted with the detaching solution as described above for water samples. Nine $\mathrm{mL}$ of this solution were added to each sample (containing $1 \mathrm{~g}$ of sediment plus $1 \mathrm{~mL}$ of water). Samples were shaken and incubated for 30 minutes in the dark (room temperature and at $150 \mathrm{rpm}$ ) to obtain a sediment extract. Then, a purification step was needed in order to obtain an enough clean sample to be counted at the flow cytometer, avoiding fine sediment particles. We used a density gradient medium ("Optiprep") following the protocol from Amalfitano \& Fazi (2008). For this procedure, for each sample, $1 \mathrm{~mL}$ of density gradient medium was added to $1 \mathrm{~mL}$ of diluted sediment extract and the sample was centrifuged for 90 minutes at $4{ }^{\circ} \mathrm{C}$. Prokaryotes were collected from the supernatant and we proceed with the same staining protocol as that described for water samples.

The cytometer used was a FACSCalibur (Becton Dickinson) equipped with an argon laser $(488 \mathrm{~nm})$. All fluorescent filters and detectors used were the standard device with green fluorescence collected in the FL1 channel and red fluorescence collected in the FL3 channel. All parameters were obtained with logarithmic signals. Generally, we acquired data at a low speed (approx. $15 \mu \mathrm{L} / \mathrm{min}$ ), and the concentration of the sample was adjusted to keep the events count to $10000 \mathrm{~s}^{-1}$.

For the water samples, we further performed a positive control by staining and counting one sample under the epifluorescence microscope to observe if we get similar prokaryote density to that measured by the flow cytometer. For this test, $0.5 \mathrm{~mL}$ of a river water sample was stained with 4'6, diamidino-2-phenylindole (DAPI, $100 \mu \mathrm{L}$ of dye were added), and then filtered through a polycarbonate membrane black $0.2 \mu \mathrm{m}$ pore size filter. Prokaryotes were counted under the epifluorescence microscope (Nikon Eclipse E600) and results obtained were very close to those measured with the flow cytometer just confirming the convenience of using our protocol. 


\section{Prokaryote viability}

A method commonly used for cell viability in aquatic ecosystems is a double stain which distinguishes cells with a damaged membrane from intact cells (live and dead kit). Although this method is not a direct metabolic measure, it has been shown to being able to distinguish the viable cells (either active, inactive, culturable, and nonculturable) from those that have the membrane damaged or compromised, and its use has been recommended for field studies (Grégory $e t$ al., 2001).

With the purpose of evaluating viable and dead bacteria in the sample, we used the commercial kit Live/Dead $\AA$ Baclight (Invitrogen). This test is based on two DNA staining dyes, Syto 9 and propidium iodide (PI), with different cell penetrability. Syto 9 (fluorescent green) spreads through the cell membrane and binds to nuclear DNA, while PI is only able to penetrate cells with damaged membranes and once inside binds to DNA, and then the combination of the two dyes becomes into a red fluorescence. Thus, "live" (membrane intact) cells are stained green, while "dead" (damaged membrane) cells are stained red.

Prokaryote viability was measured for one replicate for each collected water site and sam- pling date. Fresh collected water samples were diluted (1/10) with MQ autoclaved water and $2 \mathrm{~mL}$ of this extract were stained with $3 \mu \mathrm{l}$ of the double dye PI + Syto 9. Samples were incubated for 15 minutes in dark conditions. Stained samples were then filtered through a polycarbonate membrane black $0.2 \mu \mathrm{m}$ pore size filter. Filters were prepared for microscope observation with immersion oil and prokaryotes were counted (Nikon Eclipse E600). At least 20 fields were counted for a total of 200-1000 cells. Microscope filters used were 450-490 nm wavelengths for green fluorescence and 510-560 nm wavelengths for red fluorescence. The results were given as total living cells per $\mathrm{mL}$ and $\%$ of living cells (green cells versus total $\times 100$ ).

\section{Data analysis}

To analyse the differences in prokaryote density and in the physico-chemical parameters in river water between sites (BEFORE, WWTP, AFTER) and river reaches (Palautordera vs Tordera) for all sampling days we performed a three-way analysis of variance (ANOVA; 3 factors: day, site and river reach). Differences between reaches considering only BEFORE sites were analysed by two-way ANOVA (factors day and river reach) to control for differences between the two

Table 1. Discharge and level for each river reach during the study period. Data correspond to the specific sites at Fogars de la Selva (located at $5 \mathrm{~km}$ from the Tordera reach) and Sant Celoni (located at $4 \mathrm{~km}$ from the Palautordera reach; ACA). The theoretical percentage of discharge input from WWTPs is also shown. This was calculated by knowing the mean discharge for each WWTP during the study period $\left(0.035 \mathrm{~m}^{3} / \mathrm{s}\right.$ in Palautordera WWTP and $0.023 \mathrm{~m}^{3} / \mathrm{s}$ in Tordera WWTP, ACA). Caudal y nivel de la columna de agua de cada tramo fluvial durante los días de muestreo. Los datos corresponden a los puntos de Fogars de la Selva (situado a 5 km del tramo de Tordera) y Sant Celoni (situado a $4 \mathrm{~km}$ del tramo de Palautordera; ACA). También se indica el porcentaje teórico de aporte de caudal por parte de las EDAR, calculado a partir del promedio de los caudales de descarga de cada EDAR durante el período de estudio $\left(0.035 \mathrm{~m}^{3} / \mathrm{s}\right.$ en la EDAR de Palautordera y $0.023 \mathrm{~m}^{3} / \mathrm{s}$ en la EDAR de Tordera, ACA).

\begin{tabular}{|c|c|c|c|c|c|}
\hline & $15 / 11 / 13$ & $25 / 11 / 13$ & $02 / 12 / 13$ & $09 / 12 / 13$ & $16 / 12 / 13$ \\
\hline \multicolumn{6}{|c|}{ Palautordera } \\
\hline Discharge $\left(\mathrm{m}^{3} / \mathrm{s}\right)$ & 0.4 & 2.1 & 1.2 & 1.0 & 0.8 \\
\hline Water Level $(\mathrm{cm})$ & 4 & 25 & 17 & 14 & 13 \\
\hline *WWTP (\%) & 8.75 & 1.67 & 2.91 & 3.5 & 4.37 \\
\hline \multicolumn{6}{|c|}{ Tordera } \\
\hline Discharge $\left(\mathrm{m}^{3} / \mathrm{s}\right)$ & 0.1 & 0.4 & 0.3 & 0.1 & 0.1 \\
\hline Water Level (cm) & 8 & 17 & 12 & 9 & 9 \\
\hline *WWTP (\%) & 23 & 5.75 & 7.67 & 23 & 23 \\
\hline
\end{tabular}

* Indicates the percentage of water input from the WWTP as the ratio between WWTP discharge to river discharge. 

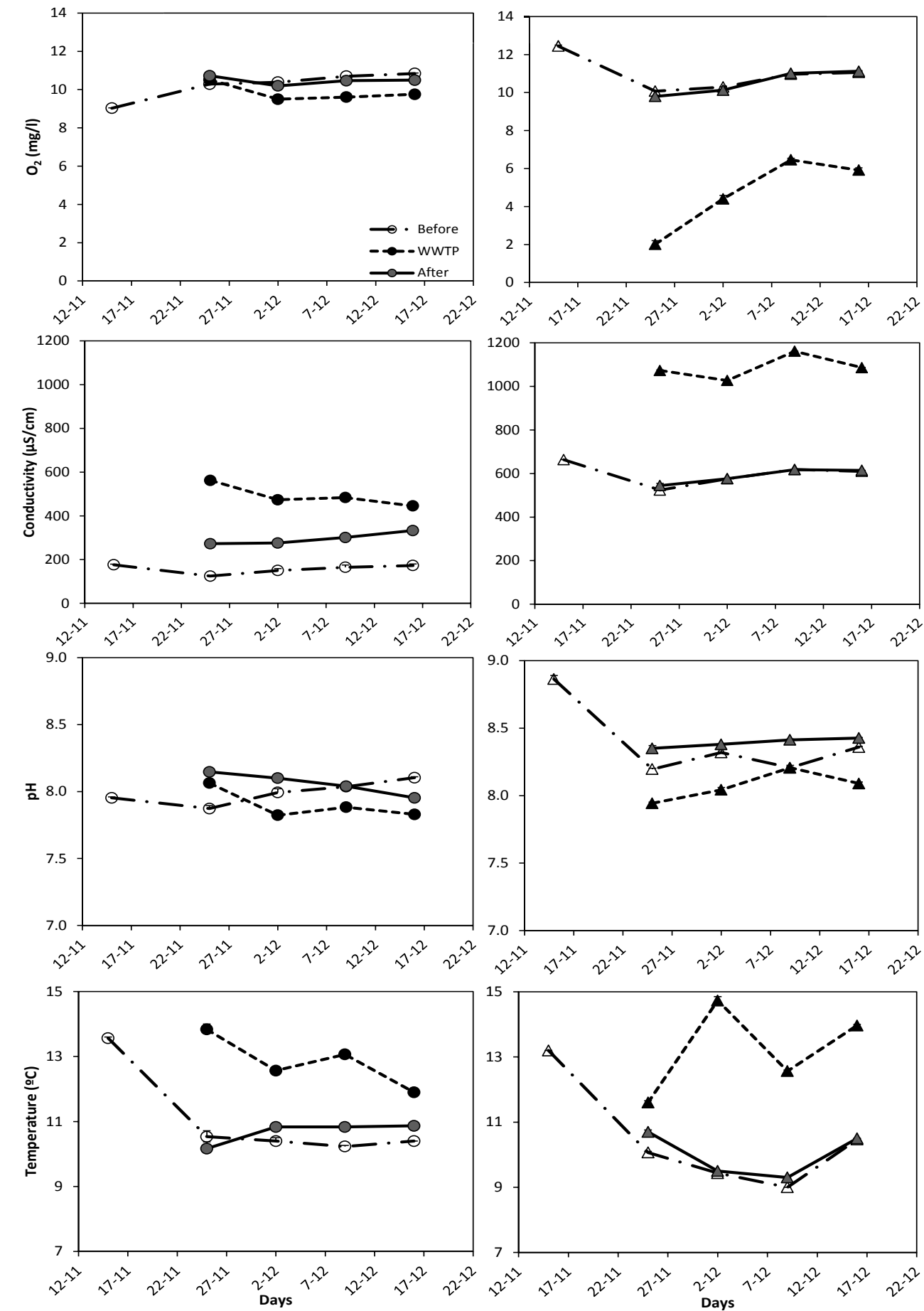

Figure 2. Concentration of dissolved oxygen, conductivity, $\mathrm{pH}$ and temperature measured at the sites Before, WWTP and After for each study reach (Palautordera, mid-river reach, and Tordera, down-river reach). Values correspond to mean values from three replicates $( \pm \mathrm{SE})$. From the first sampling date only data from the Before sites are available. Concentración de oxígeno disuelto, conductividad, pH y temperatura del agua en los puntos de Before, WWTP y After para cada tramo de estudio (Palautordera, midriver reach, y Tordera, down-river reach). Los valores corresponden a las medias de tres réplicas ( \pm error estándar). Del primer día de muestreo hay solo datos físicoquímicos de los puntos Before. 

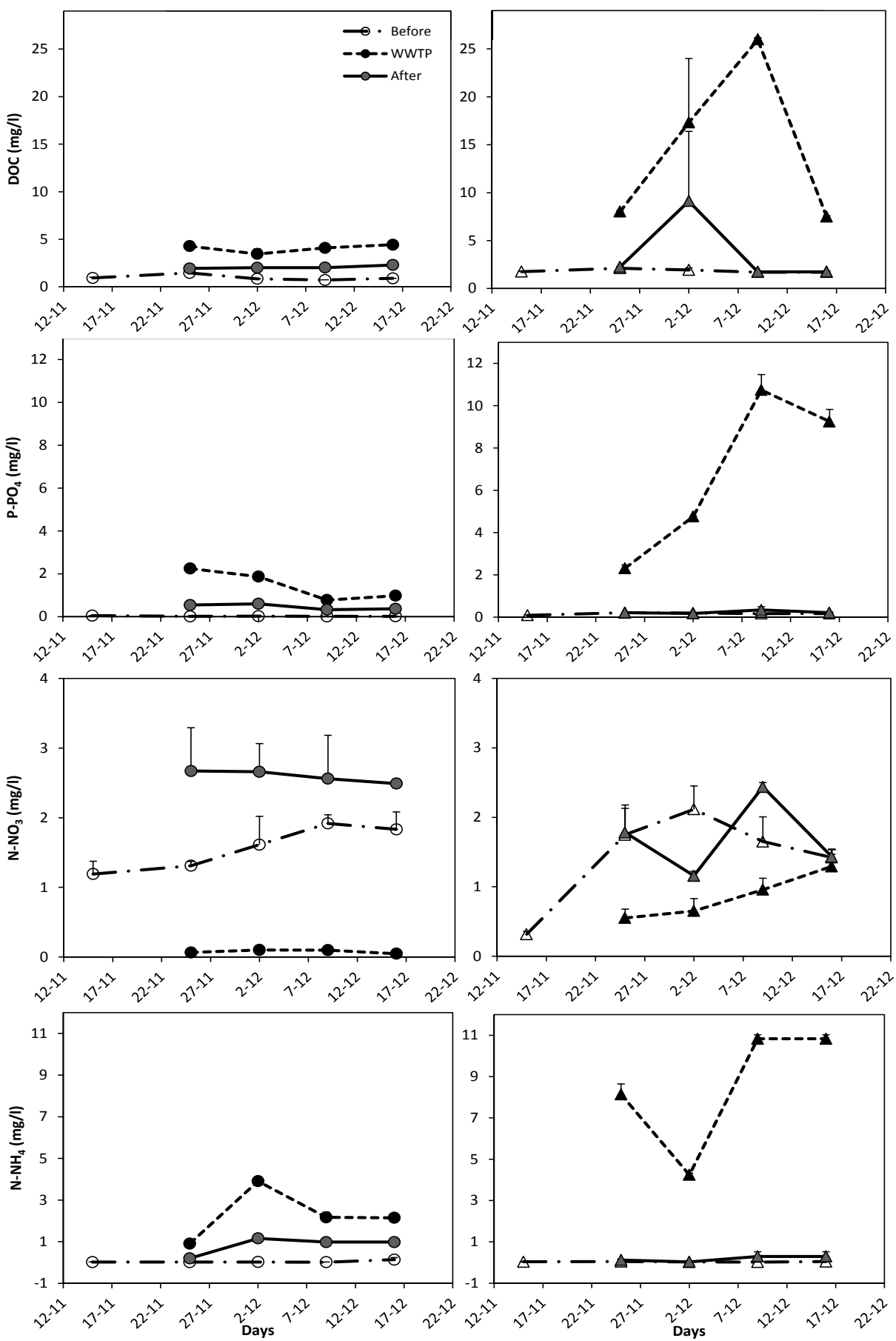

Figure 3. Concentration of dissolved organic carbon (DOC), phosphorus (in the form of phosphates) and nitrogen (in the form of nitrate and ammonia) at the sites Before, WWTP and After for each study reach (Palautordera, mid-river reach, and Tordera, down-river reach) for each sampling day. Values correspond to mean values from three replicates ( \pm SE). From the first sampling date only data from the Before sites are available. Concentración de carbono orgánico disuelto (DOC), fósforo (en forma de fosfatos) y nitrógeno (en forma de nitratos y amonio) en los puntos Before, WWTP y After en cada tramo de estudio (Palautordera, mid-river reach, y Tordera, down-river reach). Los valores corresponden a las medias de tres réplicas ( \pm error estándar). Del primer día de muestreo hay solo datos físico-químicos de los puntos Before. 
river reaches before being affected by WWTP inputs. A further ANOVA by considering the six sampling sites together was performed for prokaryote density followed by the Tukey-b test (considering a $p$-value $<0.05$ ) in order to observe significant differences between all six sampled sites. Differences in cell viability between sites and reaches were analysed by a two-way ANOVA by including results from all five sampling dates. Differences in the density of prokaryotes in the sediment between river reaches (Palautordera vs Tordera) and sampling sites (BEFORE and AFTER) were analysed by a two-way ANOVA.

In order to show the differences between sites and highlight the most relevant drivers for these differences, a multidimensional scaling (MDS) analysis was performed. Previously, a Bray Curtis similarity matrix was constructed including bacterial density and viability data and the physico-chemical parameters. Then, parameters were fitted to the NMDS plot using Pearson correlations. This analysis was performed using the Primer 6 PERMANOVA (V.6) computer program (Primer-E, Plymounth UK).

All data were transformed $(\log (x+1)$ before the analysis to achieve normality, except for the percentage of viable cells and $\mathrm{pH}$.

\section{RESULTS}

During the study period discharge was higher in Palautordera than in Tordera and the average percentage of water from WWTP contribution to the river was $4.2 \%$ in Palautordera and $16.4 \%$ in Tordera (Table 1).

The Palautordera reach had lower oxygen concentration, conductivity, $\mathrm{pH}, \mathrm{DOC}$, and phosphate than the Tordera reach $(p<0.02$ for all parameters) but both reaches had similar temperature and nitrate and ammonia concentration (Fig. 2 and 3). WWTP effluents showed higher conductivity, temperature and concentration of DOC, phosphate and ammonia, but lower nitrate concentration and $\mathrm{pH}$ than the receiving river waters (Fig. 2 and 3). Moreover, the Tordera WWTP showed significantly lower oxygen concentration than the receiving river water (Fig. 2). Most of the physical and chemical parameters analyzed in the river water were affected by the WWTP input, but this effect was different depending on the river reach (Table 2 , ANOVA; Reach $\times$ Site interaction), the Palautordera showing greater effects than the Tordera.

Density of prokaryotes presented similar values between the two river reaches (Fig. 4) with values around $10^{7}$ cell $/ \mathrm{ml}$. However, significant differences between sampling days and sites were observed (Table 2). Particularly, there was higher prokaryote density at the WWTP outputs than in the river main stem sites, but the WWTP input affected differently the two reaches since higher prokaryote densities were measured at the Palautordera AFTER site than at the Tordera AFTER site (Fig. 4, Table 2, Reach $\times$ Site interaction). Accordingly, the Tukey-b test grouped together the two WWTP and the Pa-

Table 2. Results from the three factor analysis of variance ANOVA ( Reach: mid-river reach, down-river reach; Sampling day (Day); Sampling site, (Sites): Before, WWTP, After) for the physyco-chemical variables and prokaryote density in sampled waters. Probability values are shown ( $p$-values $<0.001$ are highlighted in bold). Resultados del análisis de la varianza de tres factores (tramo de estudio, Reach (R): mid-river reach, down-river reach; Día de muestreo (Day); punto de muestreo, Site (S): Before, WWTP, After) para las variables físicoquímicas y la densidad de procariotas en el agua. Se muestra el valor del nivel de significación; $\mathrm{p}$-valor $<0.001$ están marcados en negrita.

\begin{tabular}{|c|c|c|c|c|c|c|c|c|c|}
\hline Source of variation & $\mathrm{O}_{2}$ & Conductivity & $\mathrm{pH}$ & $\mathrm{T}^{\mathrm{a}}$ & DOC & $\mathrm{P}-\mathrm{PO}_{4}$ & $\mathrm{~N}-\mathrm{NO}_{3}$ & $\mathrm{~N}-\mathrm{NH}_{4}$ & Cell $/ \mathrm{mL}$ water \\
\hline Reach & $<0.001$ & $<0.001$ & $<0.001$ & $<0.001$ & $<0.001$ & $<0.001$ & 0.473 & 0.083 & 0.093 \\
\hline Day & $<0.001$ & $<0.001$ & $<0.001$ & $<0.001$ & 0.508 & 0.356 & 0.257 & $<0.001$ & $<0.001$ \\
\hline Sites & $<0.001$ & $<0.001$ & $<0.001$ & $<\mathbf{0 . 0 0 1}$ & $<0.001$ & $<0.001$ & $<\mathbf{0 . 0 0 1}$ & $<0.001$ & $<0.001$ \\
\hline Day $\times$ Reach & $<0.001$ & 0.302 & $<0.001$ & $<0.001$ & 0.021 & $<0.001$ & $<0.001$ & $<0.001$ & 0.057 \\
\hline Day $\times$ Sites & $<0.001$ & $<0.001$ & $<0.001$ & $<0.001$ & 0.02 & 0.285 & 0.475 & 0.01 & $<0.001$ \\
\hline Reach $\times$ Sites & $<0.001$ & $<0.001$ & $<0.001$ & $<0.001$ & $<0.001$ & $<0.001$ & $<\mathbf{0 . 0 0 1}$ & $<\mathbf{0 . 0 0 1}$ & $<0.001$ \\
\hline Day $\times$ Reach $\times$ Sites & $<0.001$ & $<0.001$ & $<0.001$ & $<0.001$ & 0.155 & $<0.001$ & 0.008 & 0.031 & 0.056 \\
\hline
\end{tabular}


PALAUTORDERA

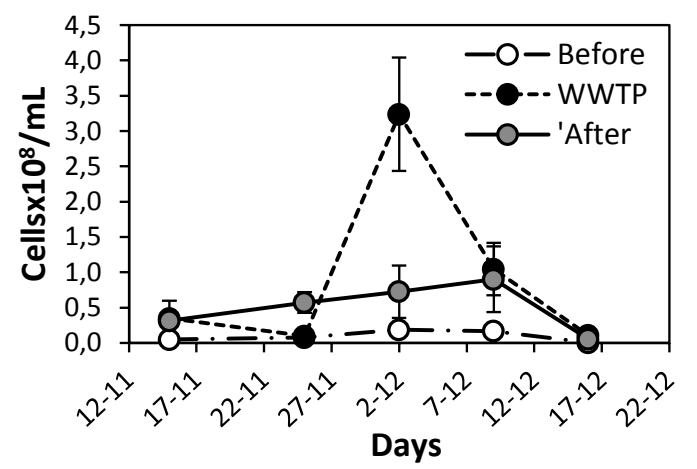

TORDERA

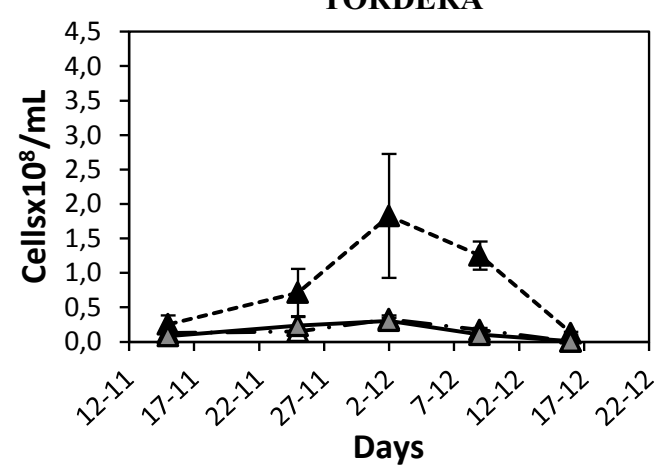

Figure 4. Density of prokaryotes from the sites Before, WWTP and AFTER for each study reach (Palautordera, mid-river reach, and Tordera, down-river reach) for each sampling day. Values correspond to mean values from three replicates \pm standard error. Densidad de procariotas obtenidas durante los días de muestreo en los puntos de Before, WWTP y After para cada tramo de estudio (Palautordera, mid-river reach, y Tordera, down-river reach). Los valores corresponden a las medias de tres réplicas \pm error estándar.
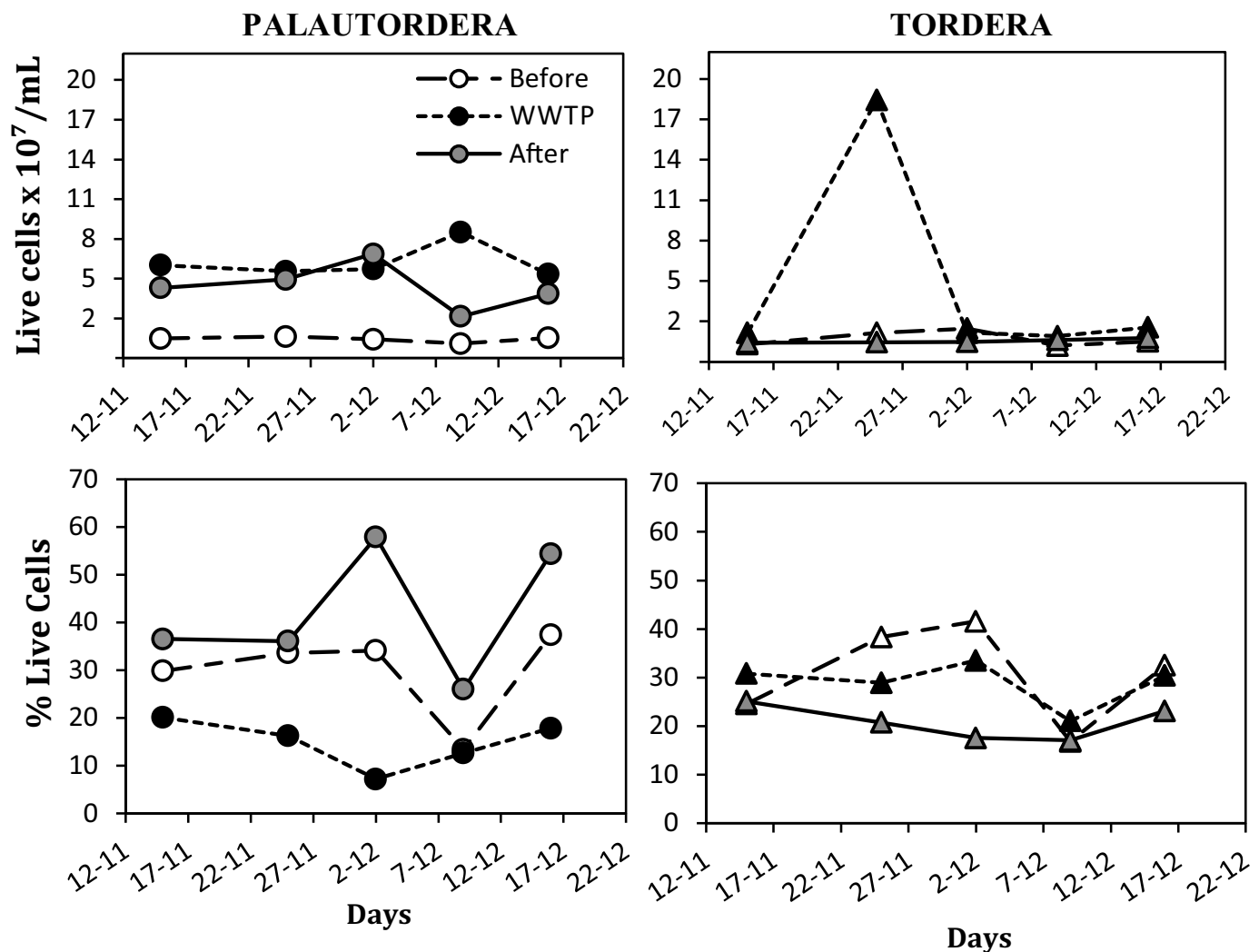

Figure 5. Density of total líving prokaryotes and percentage of living cells from the sites Before, WWTP and AFTER for each study reach (Palautordera, mid-river reach, and Tordera, down-river reach) for each sampling day. Values correspond to individual results measured after counting at the epifluorescence microscope. Densidades de procariotas viables totales y porcentage de procariotas viables para los distintos días de muestreo en los puntos de Before, WWTP y After para cada tramo de estudio (Palautordera, mid-river reach, y Tordera, down-river reach). Los valores corresponden a valores individuales obtenidos mediante recuento en el microscopio de epifluorescencia. 
lautordera AFTER site as having significantly higher prokaryote density than the two BEFORE sites and the AFTER Tordera site (Tukey test, $p$-value $<0.05)$.

In the case of viability of planktonic prokaryotes, we founded higher abundances of living prokaryotes at the Palautordera compared to the Tordera reach (Reach effect, $p$-value $=0.002$, Fig. 5). There were significant differences between sites, mainly due to higher living prokaryote densities at the WWTP sites (Site effect, $p$-value $<0.001)$. However, the significant interaction between Reach and Site effect ( $p$-value $=0.003$ ) indicated a relevant increase in living prokaryotes at the AFTER Palautordera site which was not observed at the AFTER Tordera site (Fig. 5).

The percentage of living prokaryote cells was around $30 \%$ and values were similar at the two river reaches (Reach effect, $p$-value $=0.50$ ). However, percentage of viable cells was increasing from BEFORE to AFTER sites at the Palautordera reach while it was decreasing at the Tordera reach (Fig. 5, significant Reach $\times$ Site interaction effects, $p$-value $=0.001$ ) .
Regarding the density of prokaryotes in river sediment, there were no significant differences between river reaches and neither between sites ( $p$-values $=0.43$ and 0.40 , respectively). However, the interaction between reach and site was significant $(p$-value $=0.038)$ due to an observed reduction of prokaryotes between BEFORE and AFTER sites in Palautordera, while in Tordera there was an increase between both sites (Fig. 6).

The MDS of prokaryote density and viability together with physical and chemical parameters analyzed indicated that samples from the WWTP were located together on the right and were characterized by higher conductivity, DOC, phosphate, ammonia and temperature. Higher prokaryote density and viability was also characterizing WWTP effluents but specially affecting the AFTER waters at the Palautordera reach (Fig. 7). At the same time, higher values of oxygen and nitrate were observed in BEFORE Palautordera. Interestingly, samples from Palautordera BEFORE and AFTER were located separately in the MDS, in contrast to the samples BEFORE and AFTER from Tordera which were closely located indicating having similar prokaryote

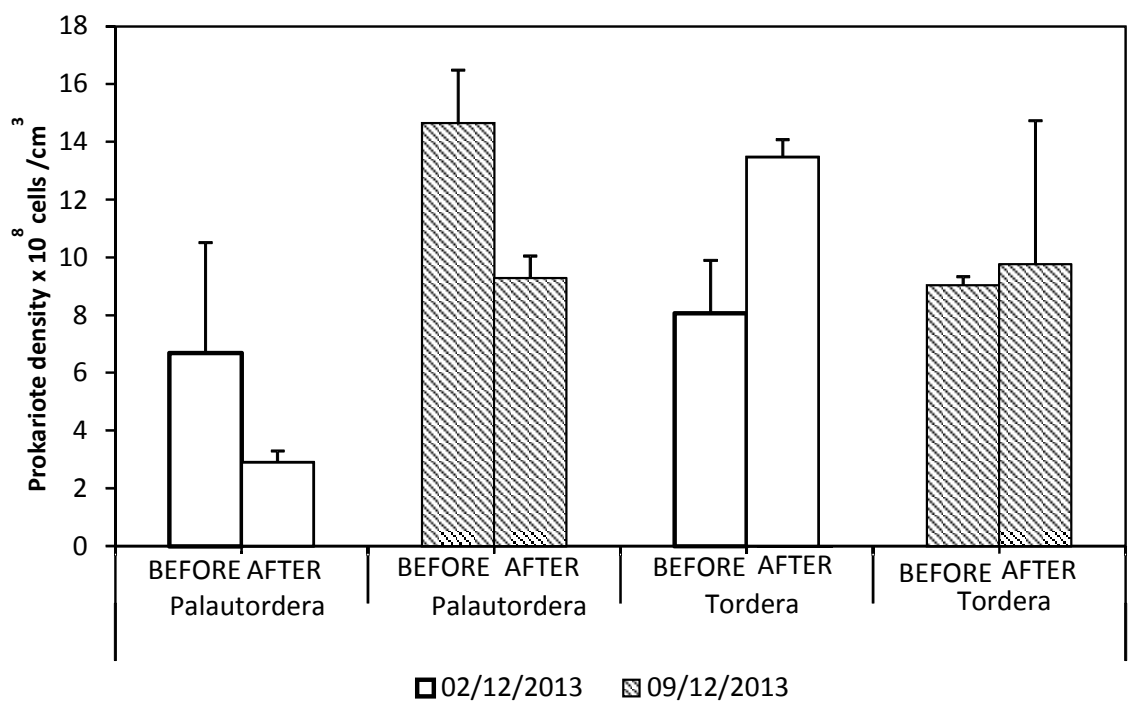

Figure 6. Prokaryote densities at the streambed sediments from the sites BEFORE and AFTER at the two study reaches (Palautordera, mid-river reach, and Tordera, down-river reach). Values correspond to mean values from three replicates \pm standard error. Densidades de procariotas en el sedimento del lecho fluvial de los puntos Before y After en los dos tramos de estudio (Palautordera, mid-river reach, y Tordera, down-river reach) para dos días de muestreo. Los valores corresponden a la media de tres réplicas \pm error estándar. 
density and viability and physico-chemical characteristics.

\section{DISCUSSION}

Density of prokaryotes at the studied Tordera river reaches was within the range of $10^{7} \mathrm{cell} / \mathrm{ml}$ and similar to values measured in mid to large rivers, such as the Ebro river (Ruiz-González et $a l .$, 2012), the Hudson river estuary (Findlay $e t$ al., 1991), the Warnow river (Warkentin et al., 2011), or the Warta river (Szelagg-Wasielewska et al., 2009). The percentage of living cells was of $28 \%$ in average, similar to values measured in other river systems (Warkentin et al., 2011) but lower to values in lentic ecosystems such as lakes (Säwström et al., 2008), or in biofilm communities (Romaní, 2010). This relatively low \% of living cells indicates that the flowing system is in general uncomfortable for the development of a bacterial community and/or that it receives also dead and damaged cells dragged by the flowing water.

At the two WWTP outflows, prokaryote densities were significantly higher than those in the river water $\left(10^{8} \mathrm{cell} / \mathrm{ml}\right.$; Fig. 4$)$. It was expected then that prokaryote density should increase at the sites receiving WWTP outlets (AFTER sites). However, this was only observed for the Palautordera reach while at the Tordera reach, prokaryote density at the AFTER site maintained the same values to that at the BEFORE site. Different mechanisms linked to the specific physical and chemical conditions at each reach and to the interactions with the sediment are proposed to drive these different observations. At the Palautordera reach we calculated the approximate expected prokaryote cell density at the site AFTER the WWTP by using the known densities at the inflows (BEFORE and WWTP) and their respective discharge values, and we obtained the expected average value of $1.7 \cdot 10^{7}$ cell $/ \mathrm{ml}$, which is similar but slightly lower than the measured mean value $5.1 \cdot 10^{7} \mathrm{cel} / \mathrm{mL}$. Although this is a rough calculation since we used discharge values from the closest gauging station and mean discharge from the WWTP during that period (Table 1), this suggests that other processes than just only the physical mixing of the two waters occur. Two processes are suggested to determine the observed increase in prokaryote
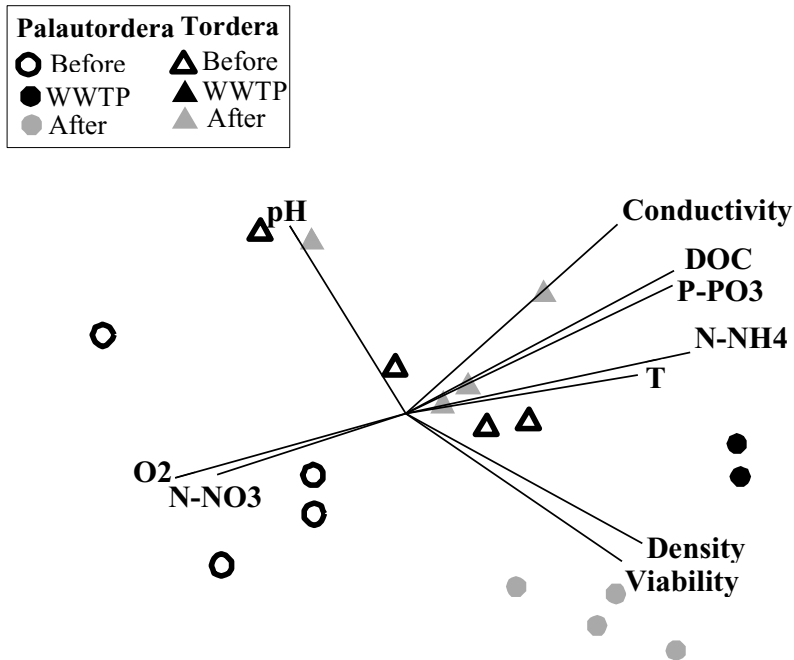

Figure 7. NMDS ordination plot including all measured physico-chemical parameters and prokaryote density and viability for the different sites BEFORE (open squares); WWTP (solid circles) and AFTER (solid triangles) in each of two reaches: Palautordera and Tordera. Kruskal 2D stress = 0.09. Ordenación NMDS que incluye los parámetros físicoquímicos de los diferentes puntos, BEFORE (cuadrados vacíos); WWTP (círculos sólidos) y AFTER (triángulos sólidos) en cada uno de los dos tramos: Palautordera y Tordera. Kruskal 2D stress $=0.09$. 
cells density at the AFTER site in Palautordera: 1) at this site probably prokaryotes in the sediment are feeding the bacterioplankton pool, and 2) prokaryotes may grow within the plankton. Some of our results support these suggestions. The observed decrease in the prokaryote density at the sediment from the AFTER site in comparison to the BEFORE site suggests that prokaryotes are being detached or loosed from the sediment and then inoculated to the planktonic pool. The inflow of water from the WWTP at this site may affect the sediment biofilms, maybe disrupting the biofilm structure. An effect of the WWTP on sediment biofilms was previously shown in a laboratory experiment performed in the Tordera river where there was an increase in dead bacteria after receiving WWTP inputs at Palautordera site (Perujo et al., 2016). Similarly a negative effect of a WWTP outlet on sediment bacteria was also shown by Drury et al. (2013). In contrast, prokaryotes in the planktonic form are increasing their density and also increase in the percentage of viable cells respecting both the BEFORE site and the WWTP inputs, indicating that they are maybe actively growing at the flowing water which could be favored by availability of dissolved organic carbon and phosphorus from the WWTP outlet. These findings might indicate a dynamic response of the bacterioplankton community making use of nutrients and organic matter entering from WWTP input and thus increasing bacterial viability.

At the Tordera reach, in contrast, prokaryote density at the river water $\left(1.5 \cdot 10^{7} \mathrm{cell} / \mathrm{ml}\right.$; Fig. 4) seemed to be not affected by the WWTP input, although the theoretical calculation would suggest an increase of prokaryote density to $2.8 \cdot 10^{7} \mathrm{cell} / \mathrm{ml}$. The limited growth of planktonic prokaryotes at this site is reflected by the decrease in the percentage of active prokaryotes. Growth of planktonic prokaryotes at this site could be affected by the low oxygen conditions of the WWTP outflow. Also, at this site, a settlement of prokaryotes from the planktonic to the benthic form after the WWTP input is suggested as shown by the increase in prokaryote density at the sediment from the AFTER site. The streambed at this reach is wider and usually having areas of low flow velocity which can favor the settlement of prokaryote cells (Steven \& Barry, 2006). At the same time, the work from Perujo et al. (2016) suggested an active growth of prokaryotes at the sediment receiving the WWTP input at this same study site.

We previously hypothesized that prokaryote density and viability in the flowing water will increase after receiving WWTP inputs due to the direct effect of the bacterial inoculum together with available inorganic and organic nutrients. However, our results indicate distinct responses of cell density and viability at the two study sites. Results further indicate that river bacterioplankton is highly dynamic (viability ranging from 13 to $57 \%$ ) and responsiveness when receiving tributaries from WWTP. The bacterioplankton is not simply positively responding to increasing loads of nutrients and organic matter from the effluent, but it is also affected by physico-chemical characteristics of the effluent water which can inhibit prokaryote growth (such as low oxygen concentration). At the same time, results suggest that when the receiving river reach have favorable conditions for the development of a riverbed biofilm, it is the benthic prokaryote community which mainly feeds from this increasing loads of nutrients and organic matter instead of the bacterioplankton, as it is observed in the low-river reach where the bacterioplankton appears to be almost not sensitive to the WWTP effluent input (Fig. 7). In conclusion, our results indicate that the expected response of increasing river bacterioplankton density and viability when receiving effluents with high loads of nutrients and organic matter, as those from WWTP, will be alleviated by specific physical and chemical characteristics of the effluent which may inhibit prokaryote growth and/or by specific riverbed characteristics which hold the development of an active benthic microbial community.

\section{ACKNOWLEDGEMENTS}

This work has been performed in the framework of project FLUMED-HOTSPOTS (CGL201130151-C02) funded by the Spanish Ministry of 
Economy and Competitiveness. We thank $\mathrm{M}$. Ángeles Gallegos for the nutrient analysis of the samples.

\section{REFERENCES}

ACA (Agència Catalana de l'Aigua) (2002) Estudi d'actualització de l'avaluació de recursos hídrics de les conques internes de Catalunya i conques catalanes de l'Ebre. Generalitat de Catalunya, Barcelona. Available at http://aca-web.gencat.cat/aca/do cuments/ca/planificacio/recursos_demandes/recur sos_cic.pdf

AEMET (Agencia estatal de meteorología). 2010. Valores climatológicos normales. Girona Aeropuerto. Available at http://www.aemet.es/es/servicioscli maticos/datosclimatologicos/valoresclimatologicos $? \mathrm{l}=0367 \& \mathrm{k}=\mathrm{cat}$

AMALFITANO, S. \& S. FAZI. 2008. Recovery and quantification of bacterial cells associated with streambed sediments. Journal of Microbiological Methods, 75: 237-243. https://doi.org/10.1016/j. mimet.2008.06.004

AMALFITANO, S., S. FAZI \& A. PUDDU. 2009. Flow cytometric analysis of benthic prokaryotes attached to sediment particles. Journal of Microbiological Methods, 79: 246-349. https://doi.org/10. 1016/j.mimet.2009.09.005

AZAM, F., T. FENCHEL, J.G. FIELD, J.S. GRAY, L.A. MEYER-REIL, F . THINGSTAD. 1983. The ecological role of water-column microbes in the sea. Marine Ecology Progress Series, 10: 257 263. https://doi.org/10.3354/meps010257

BROOKS, B.W., T.M. RILEY, R.D. TAYLOR. 2006. Water quality of effluent-dominated ecosystems: ecotoxicological, hydrological, and management considerations. Hydrobiologia, 556: 365-379. https: //doi.org/10.1007/s10750-004-0189-7

CAILLE, F., J.L. RIERA, B. RODRÍGUEZ-LABAJOS, H. MIDDELKOOP, A. ROSELL-MELÍ. 2007. Participatory scenario development for integrated assessment of nutrient flows in a catalan river catchment. Hydrology and Earth System Sciences, 11: 1843-1855. https://doi.org/10.5194/hes sd-4-1265-2007

CHIARAMONTE, J.B., M.d.C. ROBERTO, T.A. PAGIORO. 2013. Seasonal Dynamics and Comunity Structure of Bacterioplankton in Upper Paraná River Floodplain. Microbiology of Aquatic Systems,
66: 773-783. https://doi.org/10.1007/s00248-0130292-2

COTNER, J.B., B.A. BIDDANDA. 2002. Small players, large role: microbial influence on biogeochemical processes in pelagic aquatic ecosystems. Ecosystems, 5: 105-121. https://doi.org/10.1007/s 10021-001-0059-3

DAVEY, H.M. \& D.B. KELL. 1996. Flow Cytometry and Cell Sorting of Heterogeneous Microbial Populations: the Importance of Single-Cell Analyses. Microbiological Reviews, 60(4): 641-696. PMCID: PMC239459.

DRURY, B., E. ROSI-MARSHALL E, J.J. KELLY. 2013. Wastewater Treatment Effluent Reduces the Abundance and Diversity of Benthic Bacterial Communities in Urban and Suburban Rivers. Applied and Environmental Microbiology, 79(6): 1897-905. https://doi.org/10.1128/aem.03527-12

ECHARRI, L. 2007. Población, ecología y ambiente. Contaminación del agua. Universidad de Navarra. Pamplona, Spain. (NO TIENE DOI).

FALCIONI, T., S. PAPA, \& J.M. GASOL. 2008. Evaluating the Flow-Cytometric Nucleic Acid DoubleStaining Protocol in Realistic Situations of Planktonic Bacterial Death. Applied and Environmental Microbiology, 74(6): 1767-1779. https://doi.org/ 10.1128/aem.01668-07

FRANCOEUR, S.N. \& B.J.F. BIGGS. 2006. Shortterm effects of elevated velocity and sediment abrasion on benthic algal communities. Hydrobiologia, 561: 59-69. https://doi.org/10.1007/14020-5070-4_4

FREESE, H.M., U. KARSTEN \& R. SCHUMANN. 2006. Bacterial abundance, activity, and viability in the eutrophic river Warnow. Microbial Ecology, 51(1): 117-27. https://doi.org/10.1007/s00248005-0091-5

FINDLAY, S., M. PACE, D. LINTS. 1991. Variability and transport of suspended sediment, particulate and dissolved organic carbon in the tidal freshwater Hudson River. Biogeochemistry, 12: 149-169. https://doi.org/10.1007/bf00002605

GRÉGORI, G., S. CITTERIO, A. GHIANI, M. LABRA,S. SGORBATI, S. BROWN, M. DENIS. 2001. Resolution of viable and membrane-compromised bacteria in freshwater and marine waters based on analytical flow cytometry and nucleic acid double staining. Applied and Environmental Microbiology, 67(10): 4662-4670. https://doi. org/10.1128/aem.67.10.4662-4670.2001 
GÜCKER, B., M. BRAUNS, M.T. PUSCH. 2006. Effects of wastewater treatment plant discharge on ecosystem structure and function of lowland streams. Journal of the North American Benthological Society, 25(2): 313-329. https://doi.org/10. 1899/0887-3593(2006)25[313:eowtpd]2.0.co;2

MARGALEF, R. 1983. Limnología. Ediciones Omega, S.A., Barcelona. https://doi.org/10.4319/lo.198 4.29.6.1349b

MURPHY, J. \& J.P. RILEY. 1962. A modified single solution method for the determination of phosphate in natural waters. Analytica Chimica Acta, 27: 31-36. https://doi.org/10.1016/s0003-2670(00)88 444-5

ODUM, J.T. FINN, E.H. FRANZ. 1979. Perturbation theory and the subsidy-stress gradient. Bioscience, 29: 349-352. https://doi.org/10.2307/1307690

PERUJO, N., A. FREIXA, Z. VIVAS, A.M. GALLEGOS, A. BUTTURINI, A.M. ROMANÍ. 2016. Fluvial biofilms from upper and lower river reaches respond differently to wastewater treatment plant inputs. Hydrobiologia, 765: 169-183. https: //doi.org/10.1007/s10750-015-2411-1

PORTILLO, M.C., S.P. ANDERSON, N. FIERER. 2012. Temporal variability in the diversity and composition of stream bacterioplankton communities. Environmental microbiology, 14(9): 2417-28. https://doi.org/10.1111/j.1462-2920.2012.02785.x

PORTER, J., J. DIAPER, C. EDWARDS \& R. PICKUP. 1995. Direct measurements of natural planktonic bacterial community viability by flow cytometry. Applied and environmental microbiology, 61(7): 2783-2786. PMCID: PMC1388502.

REYNOLDS, C.S. 2000. Hydroecology of river plankton: the role of variability in channel flow. Hydrological Processes, 14(16-17): 3119-3132. https: //doi.org/10.1002/1099-1085(200011/12)14:16/17 $<3119$ ::aid-hyp137>3.0.co;2-6

REARDON, J., J.A. FOREMAN, R.L. SEARCY. 1966. New reactants for the colorimetric determination of ammonia. Clinica chimica acta, 14(3): 403-405. https://doi.org/10.1016/0009-8981(66) 90120-3

REHMANN, C.R. \& M.L. SOUPIR. 2009. Importance of interactions between the water column and the sediment for microbial concentrations in streams, Water Research, 43(18): 4579-4589. https: //doi.org/10.1016/j.watres.2009.06.049

RODRIGUEZ, P. 2011. Determinación del oxigeno disuelto $(O D)$ en muestras de agua. Práctica 6. La- boratorio de Química general. Web: www.puraqui mica.files.wordpress.com

ROMANÍ, A.M. 2010. Freshwater Biofilms. In: Biofouling (S. Dürr, JC Thomason) Oxford, UK: Blackwell Publishing. 10: 137-153. https://doi.org/10. 1002/9781444315462.ch 10

ROVIRA, A. \& R.J. BATALLA. 2006. Temporal distribution of suspended sediment transport in a Mediterranean basin: the lower Tordera (NE Spain). Geomorphology, 79(1-2): 58-71. https://doi.org/ 10.1016/j.geomorph.2005.09.016

RUIZ-GONZÁLEZ, C., T. LEFORT, M. GALÍ, M. MONTSERRAT SALA, R. SOMMARUGA, R. SIMÓ, J. M. GASOL. 2012. Seasonal patterns in the sunlight sensitivity of bacterioplankton from Mediterranean surface coastal waters. FEMS Microbiology Ecology, 79(3): 661-674. https://doi. org/10.1111/j.1574-6941.2011.01247.x

SÄWSTRÖM, C., I. PEARCE, A.T. DAVIDSON, P. ROSÉN \& J. LAYBOURN-PARRY. 2008. Influence of environmental conditions, bacterial activity and viability on the viral component in $10 \mathrm{An}$ tarctic lakes. FEMS Microbiology Ecology, 63(1): 12-22. https://doi.org/10.1111/j.1574-6941.2007. 00407.x

SZELĄG-WASIELEWSKA, E., T. JONIAK, M. MICHAŁKIEWICZ, T. DYSARZ, B.B. MĄDRECKA. 2009. Bacterioplankton of the Warta River in relation to physicochemical parameters and flow rate. Ecohydrology \& Hydrobiology, 9(2-4): 225236. https://doi.org/10.2478/v10104-010-0008-X

VIES-REGO, J., P. LEBARON, G. NEBE-VON CARON. 2000. Current and future applications of flow cytometry in aquatic microbiology. FEMS Microbiology Reviews, 24(4): 429-448. https://doi.org/ 10.1111/j.1574-6976.2000.tb00549.x

WAISER, M.J., V. TUMBER, J. HOLM. 2010. Effluent-dominated streams. Part 1: presence and effects of excess nitrogen and phosphorus in Wascana Creek, Saskatchewan, Canada. Environmental toxicology and chemistry, 30(2): 496-507. https: //doi.org/10.1002/etc.399

WARKENTIN, M., M.H. FREESE, R. SCHUMANN. 2011. Bacterial Activity and Bacterioplankton Diversity in the Eutrophic River Warnow-Direct Measurement of Bacterial Growth Efficiency and Its Effect on Carbon Utilization. Microbial Ecology, 61(1): 190-200. https://doi.org/10.1007/s002 48-010-9729-z

Con la colaboración de:

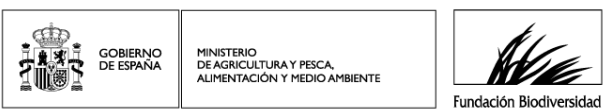

